\title{
Benign Uvula Neoplasm
}

National Cancer Institute

\section{Source}

National Cancer Institute. Benign Uvula Neoplasm. NCI Thesaurus. Code C35698.

A non-metastasizing neoplasm that arises from the uvula. 